\title{
Conflict and Its Social Impact in Kosovo
}

\author{
Rudina Hoxha \\ PhD candidate, lecturer, Departament of Sociology \\ Faculty of Education, 'Aleksander Moisiu' University, Durres, Albania \\ Email: rudihoxha@yahoo.com
}

Doi:10.5901/ajis.2013.v2n11p87

\begin{abstract}
This article discusses the role of conflict in society and the associated human relations. Through this article is aimed to give a reflection of sociological and political theories on conflict. A competitive society can be based only in a well-educated population, undressing it from all types of prejudices and discriminatory features and problems. To analyze existential and vital elements such as ethnicity, security, stability, stereotypes etc. for the society and the possible reasons why these represent causes of relationships under conflict, research of theoretical and factual data that influence these relationships need to be done. The main purpose of the study is the confrontation of approaches as two different viewpoints of the same issue (conflict situation), which brings innovation in the crosscut and changes of these relationships in conflict. Democratic rights, economic strength - and how it is distributed - social cohesion, environmental balance and well educated people cannot be separated in today's world. We need more than ever to deal with our common future in a holistic way. The only way democracy will prove itself is through a living relationship between peoples and their governments based on trust, accountability and the determination to deliver practical results.
\end{abstract}

Keywords: conflict, ethnicity, social transformations

\section{Introduction to Sociological Ethnic Approaches}

Marxism put an emphasis on social conflict was the defining characteristic of Marxism, whereas an emphasis on social consensus was the defining characteristic of structural functionalism. More specifically, this classification contrasted the legacy of Karl Marx and class analysis with the influence of Talcott Parsons who allegedly ignored or neglected conflict in favor of the study of how shared values underpin social order. This simple classification is now regarded as inadequate because any theory of conflict will imply a theory of consensus, and therefore sociologists will inevitably have to address both aspects of social life.

Marx's theory of social class conflict continues to be a foundation of any general analysis of conflict in capitalism. Whereas classical economists had recognized that a major source of conflict in society was the struggle over resources, and hence scarcity is the principal driving force behind conflict over access to goods in a competitive market, Marx concentrated on the emergence of social classes in capitalist societies, where there is a structural contradiction between the interests of workers, who want higher wages, and those of capitalists, who want higher profits. Conflict in modern societies, according to this theory, is primarily economic conflict. Marx's analysis of capitalism was modified by Ralph Dahrendorf in his Class and Class Conflict in an Industrial Society (1959) who argued that in modern industrial relations policy there had been an institutionalization of conflict because industrial disputes were often settled by negotiation between trade union officials and the managers of firms. In the early stages of capitalism, disputes between workers and capitalists could always escalate into strikes, social disruption, or revolution. In advanced capitalist societies, such disputes were managed through bargaining processes that avoided the revolutionary potential of industrial conflict, but such industrial settlements, when they resulted in a wages spiral, often resulted in inflation.

In contrast with Marxism, Max Weber's sociology was seen to provide a more flexible and subtle understanding of conflict over power. Resources in human societies are diverse; they include economic, cultural, and honorific or status resources. In Weber's conflict sociology, groups attempt to monopolize access to resources through various strategies of power that involve some form of social closure.

In contrast with Marxism, Max Weber's sociology was seen to provide a more flexible and subtle understanding of conflict over power. Resources in human societies are diverse; they include economic, cultural, and honorific or status resources. In Weber's conflict sociology, groups attempt to monopolize access to resources through various strategies of power that involve some form of social closure. 


\section{Conflict Dynamics in Kosovo}

Kosovo became an independent state on 17 February 2008 with its declaration of independence and subsequent recognition by most Western countries. With the declaration it became the last country to emerge from the 17-year process of dissolution of the former socialist state of Yugoslavia.

In 1912, Kosovo was occupied and annexed by Serbia and then integrated into Kingdom of Yugoslavia (1918) and, later, into the Socialist Federal Republic of Yugoslavia (1945). These historic events did not include the consent of Kosovo Albanians, a group that constituted the vast majority of the territory's population. In post-World War II Yugoslavia, Kosovo was an autonomous province and its status was gradually enhanced in the period between the Federal Constitution of 1946 and the Federal Constitution of 1974. Beginning in 1974, Kosovo enjoyed veto rights at both the federal and Serbian level. Kosovo's consent was required for all executive, legislative and judicial decisions at both levels. In all aspects, Kosovo's status as an autonomous province was virtually the same as that of other republics, and it remained part of Serbia in name only.

In 1989, in violation of both Kosovo's and the Federal Constitution, Belgrade abolished Kosovo's autonomy and established a repressive police and military regime in the region. Kosovo Albanians were expelled from public service. Throughout the 1990s, Kosovo was ruled directly from Belgrade, with the local Serbian community playing a significant role in implementing Serbia's rule over Kosovo. The majority of Kosovars, led by the Democratic League of Kosovo (LDK), chose peaceful resistance that aimed at defying the exercise of Serbia's authority over the territory and building a system of "parallel government institutions." The failure of peaceful resistance to provide a way out and political solution combined with increasing repression by Belgrade culminated in the emergence of the Kosovo Liberation Army (KLA) and armed conflict in 1998. The conflict was brought to an end through the military intervention of the North Atlantic Treaty Organization (NATO) in the spring of 1999. Following the end of the war, in June 1999, an international administration was established in Kosovo through U.N. Security Council Resolution 1244, which administered the territory until early 2008. The U.N. Interim Administration Mission in Kosovo (UNMIK) was designated as the authority holding civilian responsibility over Kosovo, while NATO's presence in Kosovo (KFOR) was responsible for the security portion of this international mission. The mission established an interim constitutional framework for provisional self-government in 2001and organized democratic elections on 17 November 2001. It also represented Kosovo internationally. Serbia still recognizes UNMIK alone as being legally empowered to negotiate with it on behalf of Kosovo. Interethnic clashes in March 2004 left many Serbs fearful for their future. The experience of the March riots led to a growing belief in much of the international community that a continued failure to resolve the final status of Kosovo would lead to yet more insecurity and instability. The result was the 2005 report by U.N. Special Envoy Kai Eide, a Norwegian diplomat, who recommended independence as the best way to promote long term stability and security in Kosovo. The Ahtisaari Plan built on this report. The period under international administration has been characterized by competing goals when it comes to state building. ${ }^{1}$

During the recent crises in Bosnia and Kosovo, the term "ethnic cleansing" was frequently used to characterize the policies being carried out in parts of the former Yugoslavia, but ethnic cleansing there can be traced back to the First World War. The term ethnic cleansing as we define it today, is an incomplete or somewhat random genocide that often occurs during declared or undeclared war. Generally there are three factors of conflict economic insecurity, cultural conflicts and territorial disputes.

\section{Impact of Conflict}

Likewise in many other conflict areas also in Kosovo violent conflict had devastating effects across a range of areas, many of which have lasting impacts.

Human toll- Violent conflict results in loss of life, disablement, rape and sexual violence, displacement and forced migration, the spread of disease and famine.

Social systems- Armed conflicts disrupt and destroy families and community life. Family systems are undermined through the deliberate targeting of women, the recruitment of children to join ranks of rebel groups, massive displacements, and losses of life and property. 
Political governance- Violent conflict impacts negatively on the rule of law, state capacity, and democratic political processes. Corruption and criminality often take root, and the influence of military actors rises.

Socioeconomic costs- Infrastructure, capital stock and household assets are destroyed during conflict, investment declines, and household and national incomes drop. The loss of livelihoods, due in part to the destruction of infrastructure and natural resources, and lack of employment opportunities coincides with a weakened social safety net and a decline in the capacity of the state to provide services, such as health and education. Socioeconomic indicators demonstrate that impacts of conflict include declining literacy, a drop in life expectancy and increased infant mortality. The collapse of education systems and the loss of educated populations (due to death or displacement) have negative long-term implications for human capital and economic productivity. The development of war economies, trade in illicit goods and a focus on informal sectors to cope with the weakening of the formal sector, can distort economic production and growth.

Social capital- The processes and impact of violent conflict weakens and in some cases destroys the social fabric of societies. Conflict disrupts social relations and can result in social dislocation, and a decline in interpersonal and communal group trust. While social capital within a group may be strengthened, social capital across groups is weakened by the destruction of the norms and values that underlie cooperation.

Social-psychological- Experiencing violent conflict can be extremely traumatic. Many war-affected persons suffer from post-traumatic stress syndrome, which contributes to poor mental and physical health, reduced quality of life, and in some cases, greater difficulties in work, education and family life - and increased violent behavior. Women who have endured sexual violence can suffer rejection in their own families and communities. Youth and children are at particular risk: research has shown that experiencing violence at an early age results in higher risk of perpetuating violence. Feelings of humiliation and betrayal, and the desire for revenge, can also perpetuate a cycle of violence in which 'underlings' rise to power, engage in extreme acts, inflicting indignities on those who had done the same to them.

Legacy of large-scale human rights abuses- Violent conflict results from and produces a breakdown in law and order and the perpetration of human rights abuses on a mass scale - by government, non-state actors, and in the case of transnational conflicts, external actors. Addressing this legacy and finding the appropriate methods to come to terms with it is a key challenge in conflict affected societies. Left unaddressed, there is the risk that grievances will persist and societies will remain locked in conflict dynamics.

Regional/global impact- Violent conflict has various effects in neighboring countries and beyond as arms, drugs, conflict resources and refugees spill over the border. Mass refugee migration in particular can place a large economic burden on host countries. Neighboring countries may also suffer from damage to cross-border infrastructure and the environmental impacts of conflict.

The early introduction of power sharing can potentially prevent identity-based conflicts from turning violent. For example, many believe that getting a power sharing agreement in Kosovo will be critical to keeping identity-related disputes in the region from further escalating into another war in the Balkans. When governments are democratic and inclusive, the argument goes, violent conflicts can be prevented because minorities won't need to resort to violence to advance their interests.

\section{Conclusion}

The dynamics of ethnic hatred and violence that were manifested in the early decades of the twentieth century established patterns of behavior that played a role in the developments of the 1990s and provide a template for gauging present and future conditions under which ethnic cleansing may occur. The ethnic conflict that erupted in the former Yugoslavia in 1990, for example, had been suppressed and held in check for almost 50 years during the years of the Eastern Bloc, but it was always present and unresolved. Authoritarian systems can present an illusion of short-term stability, but are unlikely to be sustainable over the long term. The fundamental problem remains of how to reconcile the legitimate interests of different communities living side by side.

\section{References}

Goutman, Roy, The Collapse of Serbia, World Policy Journal, Spring 1999, pp 12-18

Bookbinder, Paul, A Bloody Tradition, Ethnic Cleansing in World War II Yugoslavia, New England Journal of Public Policy, 2001

Business Monitor International's monthly report on political risk and macroeconomic prospects, Emerging Europe monitor, vol 12, Issue 7, July 2005

Cviic, Christopher, Kosovo 1945-2005, International Affairs 81, 4, 2005, 851-860

Weller, Marc Kosovo's final status, International Affairs 84. 6. 2008, 1223-1243 
E-ISSN 2281-4612

ISSN 2281-3993
Academic Journal of Interdisciplinary Studies MCSER Publishing, Rome-Italy
Vol 2 No 11

October 2013

Kosovo Country report, Bertelsmann Stiftung, Gütersloh, 2012 